International Journal of Life Sciences
Available online at www.sciencescholar.us
Vol. 4 No. 2, August 2020, pages: 42-xx
e-ISSN: 2550-6986, p-ISSN: 2550-6994
https://doi.org/10.29332/ijls.v4n2.438

\title{
The Response of Sycanus aurantiacus Ishikawa Et Okajima (Hemiptera: Reduviidae) to Color Polymorphisms Larvae of Spodoptera exigua (Hubner) (Lepidoptera: Noctuidae)
}

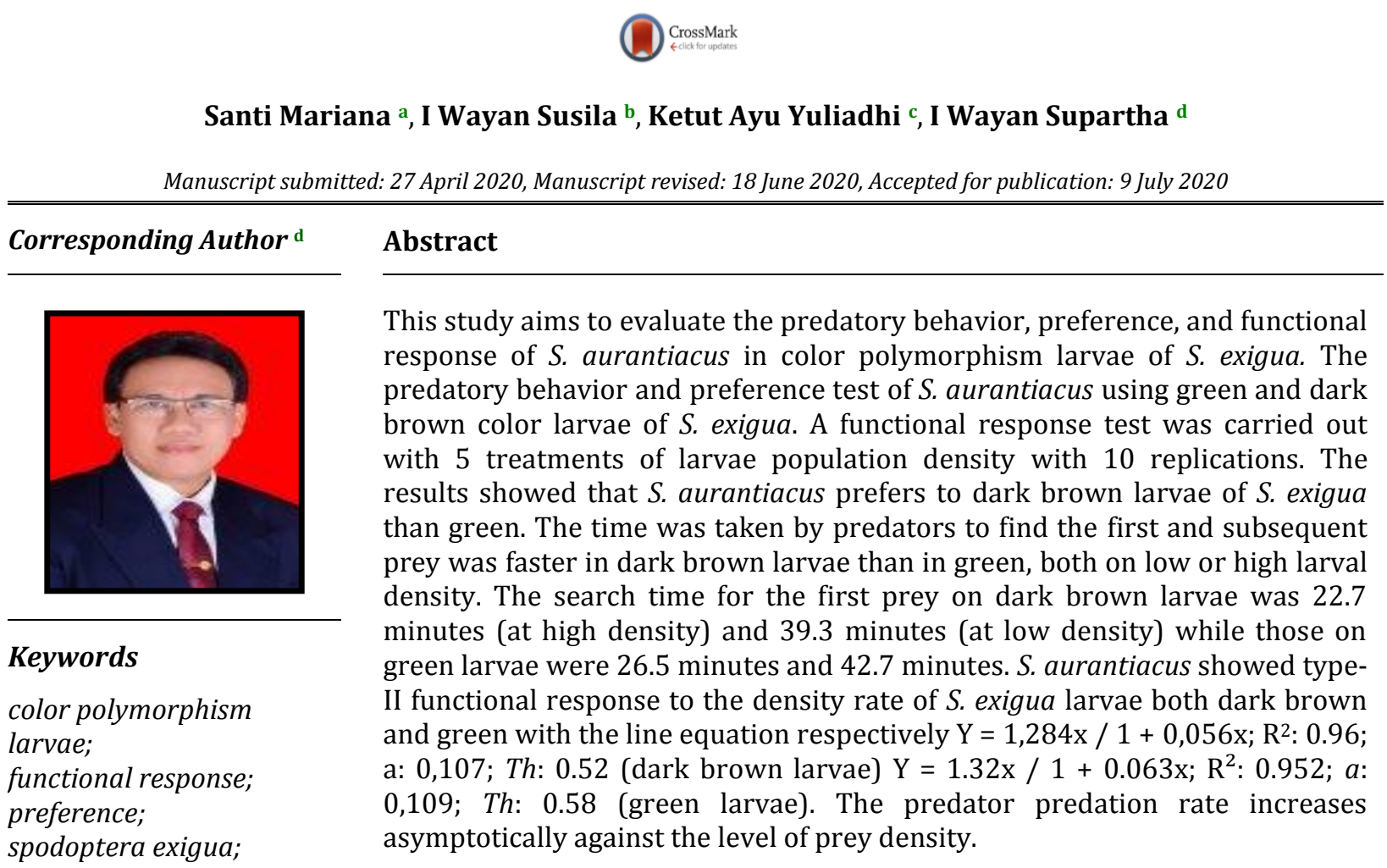

International Journal of Life Sciences (C) 2020.

This is an open access article under the CC BY-NC-ND license (https://creativecommons.org/licenses/by-nc-nd/4.0/).

\footnotetext{
Contents

Abstract

1 Introduction.

2 Materials and Methods

${ }^{a}$ Magister Student of Dryland Agriculture, Faculty of Agriculture, Udayana University, Denpasar, Indonesia

b Faculty of Agriculture, Udayana University, Denpasar, Indonesia

c Faculty of Agriculture, Udayana University, Denpasar, Indonesia

${ }^{d}$ Faculty of Agriculture, Udayana University, Denpasar, Indonesia
} 


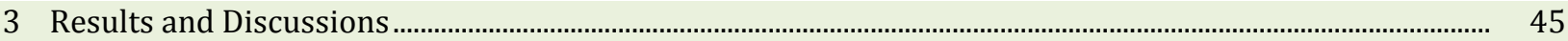

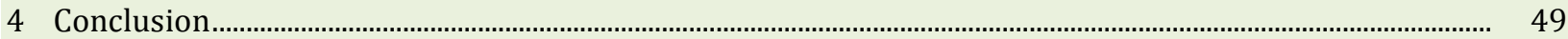

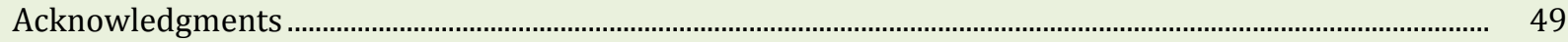

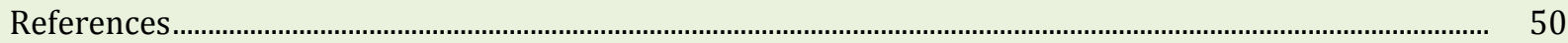

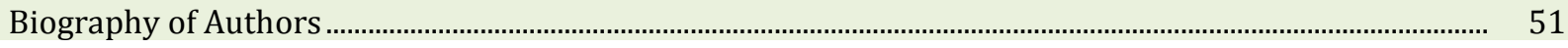

\section{Introduction}

The onion armyworm, Spodoptera exigua (Hubner) (Lepidoptera: Noctuidae) is one of the major pests that attack shallots in Indonesia. Losses caused by $S$. exigua larvae attacks could reach $100 \%$ if proper control is not carried out. S. exigua attacks onion plants especially on the leaves, both young and old leaves. Under certain conditions, $S$. exigua attacks are also found on the bulbs of the onion plant. After hatching from the eggs, the young worms immediately pierce the leaf tips and then entering the leeks, as a result, the leaf tips are appeared to be hollowed or cut. The worms then conducting self-feeding activities by scraping the inner surface of the leaf, while the outer epidermis is left unscraped so that the surface of the leaf appears transparent (Moekasan et al., 2012; Supartha, et al. 2019).

S. exigua larvae that attack shallots undergo five phases of instar changes followed by changes in body color that varies from green to dark brown. Research on body color changes known as polymorphisms had been done before. Rauf (1999) reported the body color pattern of S. exigua is closely related to the number of larval populations in the field. At the time of low population (endemic) larvae are generally bright green, while at the time of population explosion (epidemic) most larvae are dark in color. The population explosion is often accompanied by the appearance of polymorphism and behavior changes. Other types of Noctuidae which are known to cause frequent population explosions are also reported to show the phenomenon of larval polymorphisms such as those of Spodoptera exempta (Walker) and Mythimna separata (Walker) (Rose, 1979; Iwao, 1961; Broadley, 1978; Brown \& Dewhurst, 1975). Cruz et al. (2018) reported that the incidence of color polymorphisms in S. exigua larvae is triggered by the influence of the quantity and quality of feed consumed by larvae. Other research also stated that the polymorphisms that occur on insects are closely related to the self-defense of insects against their natural enemies. The existence of these color changes could disrupt the predator's vision for its prey. Predators tend to prefer prey types that are visually more beneficial to them (Poulton, 1890; Fukuda et al., 1993).

In the process of prey hunting, the predators take the advantage of visual color of the larva's body to determine their choices. Therefore, the phenomenon of color polymorphism could be taken into consideration in the practice of integrated pest control (IPM) through the use of natural enemies, especially from predatory groups. The use of natural enemies, especially from predators, has been reported to show positive results and could reduce the use of chemicals that have a damaging impact on the environment. Sycanus aurantiacus Ishikawa et Okajima (Hemiptera: Reduviidae), is a type of predator that has the main prey of Lepidoptera larvae, grubs, plant lice, and other pests (Matheson, 1951; Huby-Chilton et al., 2006). Research on predation of predator species had been done previously by Yuliadhi et al. (2015) on larvae of Plutella xylostela and Croccidolomia pavonana (Lepidoptera). This research was focused on looking at the response and behavior of these predators to the prey color differences or the color polymorphisms of Lepidoptera larvae, namely Spodoptera exigua. The polymorphism is a well-known phenomenon, one of which is a basic mechanism of defending itself from the attacks by natural enemies. However, to date, a detailed report on the response of $S$. aurantiacus to the occurrence of color polymorphisms of $S$. exigua has never been reported before. Therefore, this study was conducted to evaluate the $S$. aurantiacus predation response to color polymorphisms of $S$. exigua through several test stages, namely (1) predation behavior test, (2) preference test and (3) $S$. aurantiacus functional response to color polymorphism of S. exigua larvae.

Mariana, S., Susila, I. W., Yuliadhi, K. A., \& Supartha, I. W. (2020). The response of sycanus aurantiacus ishikawa et okajima (hemiptera: reduviidae) to color polymorphisms larvae of spodoptera exigua (hubner) (lepidoptera: noctuidae). International Journal of Life Sciences, 4(2), 42-51. https://doi.org/10.29332/ijls.v4n2.438 


\section{Materials and Methods}

The study was conducted in 2 stages, firstly collecting $S$. exigua larvae from the field. The larvae were taken from the shallots that were attacked in the shallot planting center of Songan Village, Kintamani District, and the collection of S. aurantiacus imago in the vegetable land owned by farmers of Pancasari Village, Buleleng Regency. The insect collection activity was intended for the propagation of test materials. The second stage, is research at the Integrated Pest and Disease Management Laboratory (IPMLaB), Faculty of Agriculture, Udayana University. The types of tests carried out include (1) predator preference for the dark and green color polymorphisms of the larvae (2) predatory behavior of predator $S$. aurantiacus on the color polymorphisms of $S$. exigua larvae, for those with dark brown and green colors, and (3) predatory functional response to the population density of the two types of larvae colors. The material used for test cages were boxes made of transparent plastic measuring $15 \times 10 \times 7 \mathrm{~cm}$ which was topped with a mylar cloth.

Test of $S$. auranticus preference on $S$. exigua larvae that are green and dark brown, each predator were fasted for 12 hours before been given to choose the prey as many as 5 green larvae and 5 dark brown larvae. The study was repeated 10 times. The number of prey that had been eaten and left uneaten were recorded (Yuliadhi et al., 2015). Predator preferences for green and dark brown larvae were calculated using the Manly (1974), preference index namely:

$$
\alpha \mathrm{i}=\log \mathrm{p}_{\mathrm{i}} / \log \mathrm{p}_{\mathrm{i}}+\log \mathrm{p}_{\mathrm{j}}
$$

Annotation:

$\alpha_{\mathrm{i}} \quad: \mathrm{i}^{\text {th }}$ prey color preferences

pi and $\mathrm{pj}$ : the proportion of $\mathrm{i}^{\text {th }}$ and $\mathrm{j}^{\text {th-}}$-type of prey left uneaten at the end of the experiment.

Preferred index values $(\alpha)$ range from 0 to 1 . Higher index values indicate a stronger preference rate.

A study on the predatory behavior of the predator was carried out in conjunction with functional response research. Observation of the process of prey hunting and preying process beginning shortly after the inoculation of predators on prey which started from 07.00 - 19.00. The prey density treatment tested was 2,4 , 6, 8, and 10 prey. Each treatment of prey density was repeated 10 times. The treatment was carried out for both forms of larvae color polymorphism, the green and dark brown colored larvae. The observed variables for the study of predatory behavior were the instantaneous prey hunting rate $(a)$ and the prey handling time of the predator $(T h)$. The time of one prey handling was taken and calculated from the time since the predator caught, ate, then left the prey. The model used to determine the rate of $S$. aurantiacus predatism on prey density (Holling, 1959):

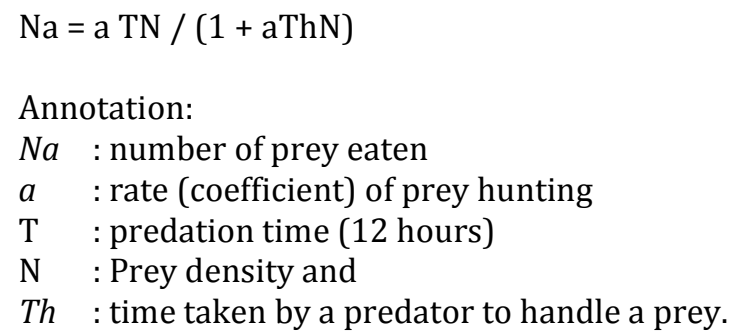

Observation of predatory behavior of predator on prey was carried out continuously by observing and recording any events related to the discovery, and handling processes of the prey and the number of predations that occurred at each rate of prey density. Observations were made on prey with a density of 2 animals representing low density and 10 densities to represent high density. Observation of predation behavior was carried out for 1 hour with an interval of 2 hours per treatment. To calculate the predator's response to prey density, the number of larvae that were preyed by predators at each level of larval population density at the end of the observation were recorded, in which 12 hours after the predator was released. 
To determine the type of functional response shown by $S$. auranticus predators against both green and dark brown colored $S$. exigua larvae, a regression analysis was performed. The type of regression analysis used was linear regression (for type I functional responses), logistics (for type-II functional responses), and sigmoid (for type III functional responses). Determination of the type of functional response had been done by comparing the value of R2 and the standard deviation from the results of the regression, linear, logistical and sigmoid analysis. The regression model chosen was the model that has the highest R2 value (close to 1) and the lowest standard deviation value among the three regression models (Jones et al., 2003; Yuliadhi et al., 2015; Wahyuni et al., 2017).

\section{Results and Discussions}

\subsection{S. aurantiacus preference on S. exigua larvae}

Preference towards prey is defined as the rate of predatory preference or distaste for the prey, which indirectly influences the predation. The degree of preference of predator $S$. aurantiacus towards the dark brown colored $S$. exigua larvae is shown by the total predation value which reached 94 percent for the dark brown colored larvae compared to the green-colored larvae pad which was 46 percent (Table 1).

Table 1

Predator preference for the dark and green color polymorphisms of the larvae

\begin{tabular}{llllll}
\hline \multirow{2}{*}{ Test } & \multicolumn{4}{c}{ Time (hour) } & \multirow{2}{*}{ Total Predation (\%) } \\
\cline { 2 - 5 } & 3 & 6 & 9 & 12 & \\
\hline \multirow{2}{*}{ Green } & $0.3 \pm 0.15 \mathrm{a}$ & $0.4 \pm 0.16 \mathrm{a}$ & $0.6 \pm 0.16 \mathrm{a}$ & $1 \pm 0,21 \mathrm{a}$ & 46 \\
\multirow{2}{*}{ Dark Brown } & $2 \pm 0.14 \mathrm{~b}$ & $1.6 \pm 0.16 \mathrm{~b}$ & $0.7 \pm 0.21 \mathrm{~b}$ & $0.4 \pm 0,16 \mathrm{~b}$ & 94 \\
\hline
\end{tabular}

The high rate of predator preference in dark brown larvae has been seen since the beginning of prey selection, namely in 3 hours after inoculation reaching 2 adults (40\%) while in green larvae only 0.3 adults (6\%). The rate of predatory preference for dark brown larvae was markedly stronger from the start of the selection at 3 hours, 6 hours, and 9 hours after inoculation. However, the preference rate was reversed at the 12 hours selection after inoculation because the number of dark brown larvae remaining were far less in number than the number of green larvae. The rates of predatory preference for dark and green-brown larvae were presented in Figure 1.

Mariana, S., Susila, I. W., Yuliadhi, K. A., \& Supartha, I. W. (2020). The response of sycanus aurantiacus ishikawa et okajima (hemiptera: reduviidae) to color polymorphisms larvae of spodoptera exigua (hubner) (lepidoptera: noctuidae). International Journal of Life Sciences, 4(2), 42-51. https://doi.org/10.29332/ijls.v4n2.438 


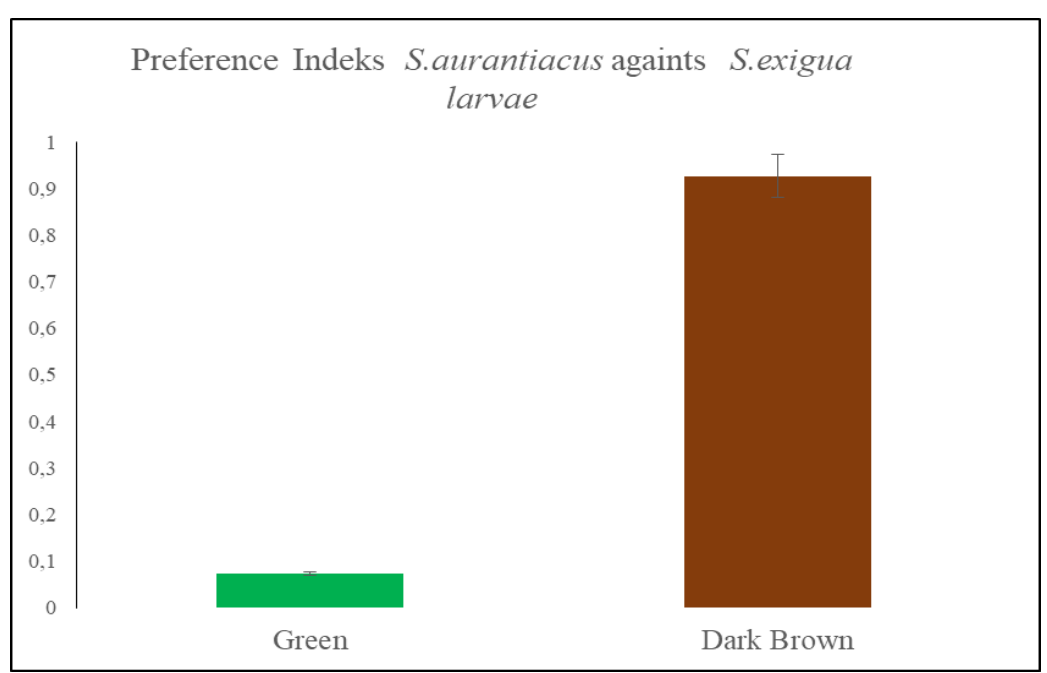

Figure 1. Preference Indeks S. aurantiacus against larva S. exigua

The highest preference index value and close to +1 was in the dark brown $S$. exigua larvae with an index value of 0.93 while the green larvae was 0.07 . The index values indicate that $S$. aurantiacus predators have a very strong preference for $S$. exigua larvae which are dark brown. The strong preference is thought to be due to the influence of the dark brown larvae wavelength which is more contrasting and more beneficial for predators. Predators take advantage of visual prey factors that have a contrasting color with their environment and are more beneficial to them (Poulton, 1890; Yin \& Chippendale, 1974). Losey et al. (1997) showed that predator Coccinella septempunctata prefers prey that is colored in contrast to its environment that is the red aphids of Acyrthosiphon pisum compared to green A. pisum which were kept in green containers. Likewise, the predator prefers $A$. pisum to be green-colored in the red container. The number of green prey eaten by $C$. septempunctata was $1.45 \pm 0.26$ while green colored $A$. pisum was $2.10 \pm 0.31$. The same case also occurred when prey infested in a green-colored container, the number of green-colored $A$. pisum that had been eaten $(1.45 \pm 0.31)$ were less than red-colored A. pisum $(2.10 \pm 0.31)$. That fact showed that red-colored $A$. pisum is more easily found by predators in green colored environments. These facts are strongly being suspected as the reason why the dark brown colored larvae are more contrasting so that it is easier to be recognized by $S$. aurantiacus than other signals such as the vibrational signals produced by the larvae when searching for food and chewing food. Research by Pfannenstiel et al. (1995) about the predator Podisus maculiventris that also uses the vibration of a mammal, worm Platypena scabra (F) when chewing food (soybean leaves) as a signal to find the prey. The study used six types of beetles namely Carabus monilis and other types of beetles from the order Coleoptera and cockroaches from the Blattodea species in Madagascar. Each prey was given dry litter, wood, and sand media, each of which could make a sound when the prey is walking. Dry litter media produces a more noisy sound that is $48 \mathrm{~h}-65 \mathrm{~dB}$ SPL (MaxRMS $0.2 \mathrm{~ms}$ ) by C. monilis beetles. The sound produced by each type of media is closely related to the size of prey insects that affect the detection distance. The sound generated by small beetles when walking across the sand, bark, and leaf litter media ranges from $60-72 \mathrm{~dB}$ SPL, while the range from 62-84 dB SPL (MaxRMS $0.2 \mathrm{~ms}$ ) for large beetles. These signals affect the detection distance of predators to their prey in the wild habitats. The predator could detect small beetles ranging from $0.9 \mathrm{~m}$ (sand) to $3.7 \mathrm{~m}$ (leaf litter). While for large beetles ranging from $1.2-12.2 \mathrm{~m}$ (40dB tropical threshold) (Pfannenstiel et al., 1995).

\subsection{Prey Hunting Time}

The results showed that predator $S$. aurantiacus requires significantly different time in the process of hunting the prey for green and dark brown larvae in both low (2 larvae) and high (10 larvae) densities (Table 2). Predator S. aurantiacus takes longer to find prey green larvae compared to prey dark brown larvae both at low and high densities. Similar incidents were also found in the subsequent prey hunting process at both low 
and high densities. The hunting time for the first prey for green larvae at low densities was 42.7 minutes and 39.3 minutes for dark brown larvae. Meanwhile, the hunting time for another prey was 129.7 minutes for green larvae and 106.1 minutes for dark brown larvae. The rate of predators in finding dark brown larvae compared to green larvae is also shown in the hunting time for prey at high densities. The average time needed to find the first prey is lower, namely 26.7 minutes for green larva prey and 22.7 minutes for dark brown larvae. While for the next prey search was 30.9 minutes for green larva prey and 27.9 minutes for dark brown larvae. As mentioned in the previous preference test (Table 1 and Figure 1) that the rate of finding the preferred prey requires a shorter time because dark brown larvae have wavelengths of color that are more contrasting than the color of green larvae (Losey et al., 1997; Otranto et al., 2000). Also, it is strongly suspected that the vibrational signals produced by dark brown larvae are more easily detected by predators than green larvae

Table 2

Prey hunting time for green and dark brown larvae in both low (2 larvae) and high (10 larvae) densities

\begin{tabular}{lllll}
\hline \multirow{2}{*}{ Test } & \multicolumn{2}{l}{ Low densities (2 larvae) } & \multicolumn{2}{l}{ High densities (10 larvae) } \\
\cline { 2 - 5 } & First Prey & Another Prey & First Prey & Another Prey \\
\hline \multirow{3}{*}{ Green } & $42.7 \pm 1,40 \mathrm{a}$ & $129.7 \pm 4,41 \mathrm{a}$ & $26.7 \pm 1,35 \mathrm{a}$ & $30.9 \pm 1,51 \mathrm{a}$ \\
Dark Brown & $39.3 \pm 0,76 \mathrm{~b}$ & $106.1 \pm 4,02 \mathrm{~b}$ & $22.7 \pm 0,5 \mathrm{~b}$ & $27.9 \pm 0,76 \mathrm{~b}$ \\
\hline
\end{tabular}

Numbers followed by the same letter in the same column are different indicates no difference real based on the t-test level of $5 \%$

\subsection{Prey Handling Time}

The handling time of one prey by the predator $S$. aurantiacus did not show a significant difference in dark brown prey and green prey both at low density and high density (Table 3 ). The average time required by a predator to handle a dark brown prey was 31.5 minutes while that of a green prey was 31.8 minutes. The average time for prey handling by predators in both dark and green brown larvae were not significantly different because the larval body size used was relatively the same. Yaninta et al. (2007) reported that predators need the same time to deal with one prey of the same body size.

Table 3

Prey handling time for green and dark brown larvae in both low (2 larvae) and high (10 larvae) densities

\begin{tabular}{lllll}
\hline Test & \multicolumn{2}{l}{ Low densities (2 larvae) } & \multicolumn{2}{l}{ High densities (10 larvae) } \\
\cline { 2 - 5 } & Green & Dark Brown & Green & Dark Brown \\
\hline $\begin{array}{l}\text { Average first prey handling } \\
\text { time }\end{array}$ & $31.8 \pm 0,91 \mathrm{a}$ & $31.5 \pm 1,08 \mathrm{a}$ & $31.1 \pm 0,69 \mathrm{a}$ & $30.9 \pm 0,72 \mathrm{a}$ \\
$\begin{array}{l}\text { Average next prey } \\
\text { handling time }\end{array}$ & $32.05 \pm 0,69 \mathrm{a}$ & $32 \pm 0,72 \mathrm{a}$ & $31.7 \pm 0,45 \mathrm{a}$ & $31.5 \pm 0,43 \mathrm{a}$ \\
\hline
\end{tabular}

Numbers followed by the same letter in the same column are different indicates no difference real based on the t-test level of $5 \%$

\subsection{Functional Response}

Functional responsiveness is one measurement to determine the effectiveness of a predator in biological control (Rogers 1972; Bianco et al., 1990). Functional responsiveness is a very important component in the relationship between predators and prey because it could provide an overview of the potential of these

Mariana, S., Susila, I. W., Yuliadhi, K. A., \& Supartha, I. W. (2020). The response of sycanus aurantiacus ishikawa et okajima (hemiptera: reduviidae) to color polymorphisms larvae of spodoptera exigua (hubner) (lepidoptera: noctuidae). International Journal of Life Sciences, 4(2), 42-51. https://doi.org/10.29332/ijls.v4n2.438 
predators in controlling prey populations. The effectiveness of predators could be seen from its functional response (Supartha \& Susila, 2001). One of the characteristics of a good predator is having a high functional response to the rate of prey density (Nelly, 2005). The results of linear, exponential and logarithmic regression analysis of predator predation results (Table 4) results showed that $S$. aurantiacus functional response types to the green and dark brown colored $S$. exigua larvae are the type-II functional responses based on the highest $\mathrm{R}^{2}$ value or close to one with the lowest standard error value. The predator predation rate increases with number of prey.

Table 4

Functional response $S$. aurantiacus againts $S$. exigua larvae with regression analysis

\begin{tabular}{|c|c|c|c|c|}
\hline Prey & Regression Analysis & $\mathrm{R}^{2}$ value & Standard error & $\begin{array}{l}\text { Functional } \\
\text { Rensponse Type }\end{array}$ \\
\hline Dark Brown S. exigua & Linear & & & \\
\hline \multirow[t]{3}{*}{ Larvae } & $Y=0,650+0,825(x)$ & 0,959 & 0,208 & \\
\hline & $\begin{array}{l}\text { Logarithmic } \\
Y=4,109 \ln (x)-1,183\end{array}$ & 0,960 & 0,060 & Type II \\
\hline & $\begin{array}{l}\text { Exponential } \\
\mathrm{Y}=1,729 \mathrm{e}^{0,176 \mathrm{x}}\end{array}$ & 0,899 & 0,228 & \\
\hline \multirow[t]{3}{*}{ Green S. exigua Larvae } & $\begin{array}{l}\text { Linear } \\
Y=0,700+0,800(x)\end{array}$ & 0,946 & 0,206 & \\
\hline & $\begin{array}{l}\text { Logarithmic } \\
Y=3,992 \ln (x)-1,089\end{array}$ & 0,952 & 0,062 & Type II \\
\hline & $\begin{array}{l}\text { Eksponensial } \\
1,727 \mathrm{e}^{0,174 \mathrm{x}}\end{array}$ & 0,891 & 0,225 & \\
\hline
\end{tabular}

Based on the type of functional response, the predation rate of predator $S$. aurantiacus to the density of their prey, in which $S$. exigua larvae, could be seen. The predator predation rate is increased by increasing the density of prey S. exigua larvae (Figure 2). Hodek \& Honek (1996) reported that effective predators could adjust their predictive abilities to their prey density.

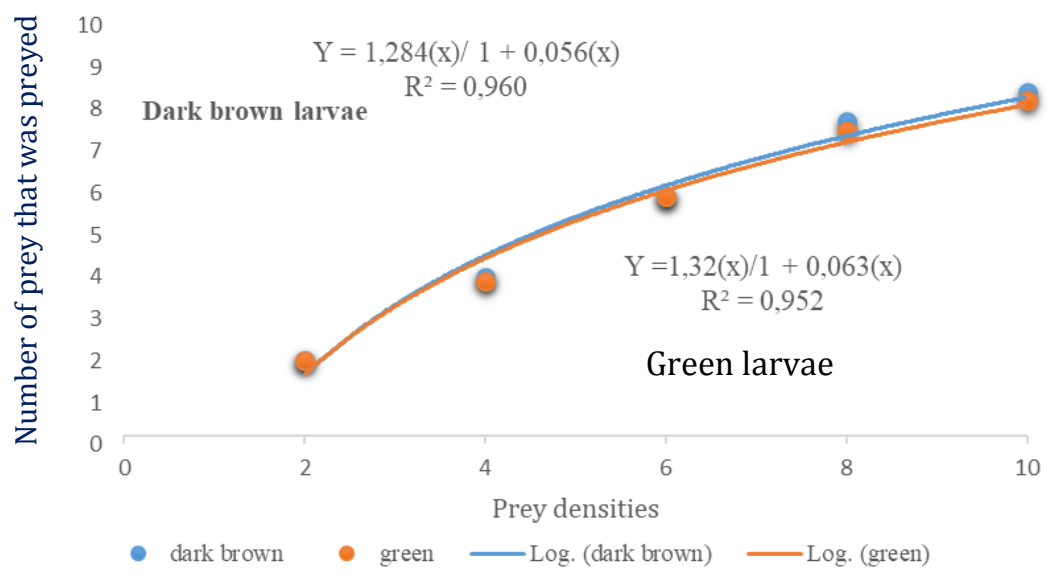

Figure 2. Predation of S.aurantiacus for some density of prey S. exigua larvae 
Important parameters of the functional response are the time of hunting the prey $(a)$ and the time of prey handling $(T h)$. The time of hunting the prey or predation rate will affect the ability of $S$. aurantiacus against $S$. exigua larvae. The higher the predation rate for $S$. aurantiacus, the more $S$. exigua will be eaten. However, when the prey density is low, the predation process is most of the time being used just to hunting on the prey, but in contrast to the condition when the prey density is high, so most of the time is being used to handle the prey (Holling, 1959). Value of $a$ in dark brown and green larvae does not have many different values, namely 0.107 (dark brown larvae) and 0.109 (green larvae). Likewise with the time needed to handle one prey (Th) each 0.52 hours/adult in dark brown larvae and 0.58 hours/adult in green larvae.

Table 5

Functional Response of S.aurantiacus for some density of prey S. exigua larvae

\begin{tabular}{lll}
\hline Test & \multicolumn{2}{l}{ S. aurantiacus adult + S. exigua larvae } \\
\cline { 2 - 3 } & Dark brown & Green \\
\hline Predation Time $(T)$ & 12 Hours & 12 Hours \\
Prey Hunting Time $(a)$ & 0,214 & 0,218 \\
Handle one prey $(T h)$ & 0,52 Hours & 0,58 Hours \\
Regression equation & $\mathrm{Y}=4,109 \ln (\mathrm{x})-1,183$ & $\mathrm{Y}=3,992 \ln (\mathrm{x})-1,089$ \\
Correlation coefficient $\left(R^{2}\right)$ & 0,960 & 0,952
\end{tabular}

\section{Conclusion}

Predator S. aurantiacus prefers dark brown to green colored S. exigua larvae. The preference index for dark brown larvae was 0.93 with total predation of $94 \%$ while the green larvae was 0.07 with total predation of $46 \%$. The time is taken by predators to hunt the first prey and subsequent prey are faster for dark brown larvae than in green larvae when the prey density is low or high. The hunting time for the first prey on dark brown larvae was 22.7 minutes (present at high density) and 39.3 minutes (at low density) while those on green larvae were 26.5 minutes and 42.7 minutes. S. aurantiacus shows type II functional responsiveness to the rate of density of both dark brown and green colored S. exigua larvae with the line equation respectively $\mathrm{Y}$ $=1,284 \mathrm{x} / 1+0.056(\mathrm{x})$; R2: 0.96; a: 0.107; Th: 0.52 (dark brown larvae) $\mathrm{Y}=1.32 \mathrm{x} / 1+0.063(\mathrm{x}) ; \mathrm{R}^{2}$ : 0.952; $\mathrm{a}$ : 0.109; Th: 0.58 (green larvae). The predation rate of the predator increases asymptotically to the rate of prey density.

\section{Acknowledgments}

The author would like to express his deepest gratitude and appreciation to the Government of Bangka Regency for the financial assistance provided for this research. The author also expresses his deepest gratitude to the Head of the Integrated Pest Management Laboratory (IPMLaB), Faculty of Agriculture, Udayana University for the facilities provided for this research. The author also thanks to his colleagues at IPMLaB for their assistance.

Mariana, S., Susila, I. W., Yuliadhi, K. A., \& Supartha, I. W. (2020). The response of sycanus aurantiacus ishikawa et okajima (hemiptera: reduviidae) to color polymorphisms larvae of spodoptera exigua (hubner) (lepidoptera: noctuidae). International Journal of Life Sciences, 4(2), 42-51. https://doi.org/10.29332/ijls.v4n2.438 


\section{References}

Bianco, A. E., Robertson, B. D., Kuo, Y. M., Townson, S., \& Ham, P. J. (1990). Developmentally regulated expression and secretion of a polymorphic antigen by Onchocerca infective-stage larvae. Molecular and biochemical parasitology, 39(2), 203-211. https://doi.org/10.1016/0166-6851(90)90059-U

Broadley, R. H. (1978). day feeding armyworm in north Queensland. Queensland agricultural journal.

Brown, E. S., \& Dewhurst, C. F. (1975). The genus Spodoptera (Lepidoptera, Noctuidae) in Africa and the near east. Bulletin of entomological research, 65(2), 221-262.

Cruz, LBC, I W. Supartha, I W Susila. (2018). Pengaruh Kualitas dan Kuantitas Pakan (Daun Bawang) terhadap Kejadian Polimorfisme Warna pada Larva Spodoptera exigua Hubner (Lepidoptera: Noctuidae). Agrotrop. 8 (2) : 129-136. https://doi.org/10.24843/AJoAS.2018.v08.i02.p03

Fukuda, M., Takagi, T., \& Shikama, K. (1993). Polymorphic hemoglobin from a midge larva (Tokunagayusurika akamusi) can be divided into two different types. Biochimica et Biophysica Acta (BBA)-General Subjects, 1157(3), 185-191. https://doi.org/10.1016/0304-4165(93)90063-E

Holling, C. S. (1959). Some characteristics of simple types of predation and parasitism. Canadian entomologist, 91(7), 385-398.

Honěk A., Hodek I. (1996) Distribution in Habitats. In: Ecology of Coccinellidae. Series Entomologica, vol 54. Springer, Dordrecht. https://doi.org/10.1007/978-94-017-1349-8_5

Huby-Chilton, F., Chilton, N. B., Lankester, M. W., \& Gajadhar, A. A. (2006). Single-strand conformation polymorphism (SSCP) analysis as a new diagnostic tool to distinguish dorsal-spined larvae of the Elaphostrongylinae (Nematoda: Protostrongylidae) from cervids. Veterinary Parasitology, 135(2), 153-162. https://doi.org/10.1016/j.vetpar.2005.08.001

Iwao, S. (1961). Studies on the phase variation and related phenomena in some lepidopterous insects. Memoirs of the College of Agriculture, Kyoto University, No. 84. 80p

Jones, D. B., K.L. Giles., R.C. Berbearet. (2003). Functional Response of an Introduction

Losey, J. E., Harmon, J., Ballantyne, F., \& Brown, C. (1997). A polymorphism maintained by opposite patterns of parasitism and predation. Nature, 388(6639), 269-272. https://doi.org/10.1038/40849

Manly, B. F. J. (1974). A model for certain types of selection experiments. Biometrics, 30(2), 281-294.

Matheson, R. (1951). Entomology for introductory courses, New York: Comstock Publishing Company.

Metcalf, R. L., \& Luckmann, W. H. (Eds.). (1994). Introduction to insect pest management (Vol. 101). John Wiley \& Sons.

Moekasan, T. K. (2012). Penerapan ambang pengendalian organisme pengganggu tumbuhan pada budidaya bawang merah dalam upaya mengurangi penggunaan pestisida. Jurnal Hortikultura, 22(1), 47-56.

Nelly, N. (2005). Dinamika Interaksi Parasitoid Eriborus argenteopilosus Cameron (Hymenoptera: Ichneumonidae) dan Inang Crocidolomia pavonana Zeller (Lepidoptera: Pyralidae) pada Kondisi Fisiologis dan Suhu Berbeda [disertasi]. Padang: Program Pascasarjana. Universitas Andalas.

Otranto, D., Tarsitano, E., Giangaspero, A., \& Puccini, V. (2000). Differentiation by polymerase chain reactionrestriction fragment length polymorphism of some Oestridae larvae causing myiasis. Veterinary Parasitology, 90(4), 305-313. https://doi.org/10.1016/S0304-4017(00)00257-0

Pfannenstiel, R. S., Hunt, R. E., \& Yeargan, K. V. (1995). Orientation of a hemipteran predator to vibrations produced by feeding caterpillars. Journal of Insect Behavior, 8(1), 1-9. https://doi.org/10.1007/BF01990965

Poulton, E. B. (1890). The colours of animals: their meaning and use, especially considered in the case of insects. D. Appleton. The International Scientific Series. Appleton and Company, New York. 400p.

Rauf, A. (1999). Dinamika populasi Spodoptera exigua (HUBNER)(Lepidoptera: Noctuidae) pada pertanaman bawang merah di dataran rendah, 11(2), 39-47.

Rogers, D. (1972). Random search and insect population models. The Journal of Animal Ecology, 369-383.

Rose, D. J. W., Rose, D. J. W., \& Rainey, R. C. (1979). The significance of low-density populations of the African armyworm Spodoptera exempta (Walk.). Philosophical Transactions of the Royal Society of London. B, Biological Sciences, 287(1022), 393-402.

Supartha, I W., A.A.I. Kesumadewi, I W. Susila, ID.G.R.Sarjana and N.W.Suniti, 2019. Integrated Management of Important Pests and Diseases of Shallots. Swasta Nulus. ISBN: 978-602-5742-43-9.

Supartha, I. W., \& Susila, I. W. (2001). Uji Pemangsaan Curinus coeruleus Mulsant(Coleoptera: Coccinellidae) terhadap Diaphorina citri Kuw. Homoptera: Psyllidae) dan Heteropsylla cubana Crawford (Homoptera: Psyllidae). Agritrop, 20(1), 5-9.

Yaninta, T. G., D. Bakti., Marheni. 2017. Daya Predasi dan Respon Fungsional Curinus coeruleus Mulsant (Coleoptera: Coccinelide) Terhadap Paracoccus marginatus Williams dan Granara De Willink (Hemiptera: Pseudococcidae) di rumah kaca. Pertanian Tropik. 4(3), 196-202. 
Yin, C. M., \& Chippendale, G. M. (1974). Juvenile hormone and the induction of larval polymorphism and diapause of the southwestern corn borer, Diatraea grandiosella. Journal of Insect Physiology,20(9), 1833-1847. https://doi.org/10.1016/0022-1910(74)90213-3

Yuliadhi, K. A., \& Pudjianto, I. S. I. W. (2015). Characteristic Morphology and Biology of Sycanus aurantiacus Ishikawa et Okajima, sp. nov.(Hemiptera: Reduviidae) on the Larvae of Tenebrio molitor L.(Coleoptera: Tenebrionidae). J. Biol. Agric. Healthc, 5, 5-8.

\section{Biography of Authors}

$\begin{aligned} & \text { Santi Mariana, SP. MP., in 2006 obtained an Agricultural graduate in the Field of } \\ & \text { Plant Pests at the Faculty of Agriculture, Udayana University. In } 2020 \text { obtained a } \\ & \text { Master of Agricultural in the field of Dry Land Agriculture at the Faculty of } \\ & \text { Agriculture, Udayana University. She is currently a Plant Pest Controller at the } \\ & \text { Food and Agriculture Office of Bangka Regency, Bangka Belitung Province- } \\ & \text { Indonesia. Email: santi.mariana@rocketmail.com }\end{aligned} \mid \begin{aligned} & \text { Prof. Ir. I Wayan Susila, MS., in 1981 obtained an Agricultural Engineer in the Field } \\ & \text { of Plant Pests at the Faculty of Agriculture, Udayana University. In 1993 obtained a } \\ & \text { Master of Science in the field of Agricultural Entomology at Bogor Agricultural } \\ & \text { University and in 2008 obtained a full professor in the field of Pest and Plant } \\ & \text { Diseases and Head of Department of Plant Protection, at Faculty of Agriculture, } \\ & \text { Udayana University, Denpasar, Bali - Indonesia. } \\ & \text { Email: w1sus@yahoo.com }\end{aligned}$

Mariana, S., Susila, I. W., Yuliadhi, K. A., \& Supartha, I. W. (2020). The response of sycanus aurantiacus ishikawa et okajima (hemiptera: reduviidae) to color polymorphisms larvae of spodoptera exigua (hubner) (lepidoptera: noctuidae). International Journal of Life Sciences, 4(2), 42-51. https://doi.org/10.29332/ijls.v4n2.438 